\title{
Anti-TNF Induced Sarcoidosis-Like Disease in Rheumatoid Arthritis Patients: Review Cases from the RA UCLouvain Brussels Cohort
}

\author{
Xavier Theunssens · Laura Bricman · Stéphanie Dierckx • \\ Emilie Sapart · Tatiana Sokolova · Aleksandra Avramovska • \\ Patrick Durez (D)
}

Received: November 19, 2021 / Accepted: January 11, 2022 / Published online: February 8, 2022

(c) The Author(s) 2022

\begin{abstract}
Introduction: Drug-induced sarcoidosis-like disease is a rare side effect of anti-tumor necrosis factor (anti-TNF) agents in rheumatoid arthritis (RA) patients. The most commonly involved organs in such condition are the lungs, skin, and lymph nodes. The aim of this study is to report the number of cases and the clinical manifestations of sarcoidosis induced by antiTNF in our RA UCLouvain Brussels cohort.

Methods: All case records of RA patients ever treated with a TNF inhibitor and presenting anti-TNF induced sarcoidosis in our rheumatology centers from 2000 to 2021 were retrospectively reviewed.

Results: Our RA UCLouvain Brussels cohort includes 2492 patients. Among them, 697 patients have been or are exposed to a TNF inhibitor. Only four patients with sarcoidosis induced by anti-TNF were identified and reviewed. Patient 1 was classified as incomplete Heerfordt syndrome. Patient 2 was a case of
\end{abstract}

X. Theunssens · L. Bricman - E. Sapart · T. Sokolova · A. Avramovska · P. Durez ( $\square)$ Rheumatology, Cliniques universitaires Saint-Luc, Institut de Recherche Expérimentale et Clinique (IREC), Université catholique de Louvain, Brussels, Belgium

e-mail: patrick.durez@uclouvain.be

S. Dierckx

Rheumatology, CHU Mont Godinne, Yvoir, Belgium sarcoid-like granulomatosis manifesting as lifethreatening hypercalcemia, acute kidney injury and atypical parenchymal pneumopathy. Patients 3 and 4 developed pulmonary sarcoidosis with hilar adenopathies. The TNF inhibitor was etanercept for the first three patients and infliximab for the last one. The time occurrence of sarcoidosis was highly variable after anti-TNF exposure. All patients recovered after glucocorticoid treatment and the discontinuation of the anti-TNF agent.

Conclusions: This case highlights this rare paradoxical side effect and the variability of the clinical presentation. Further studies should analyze the immunopathology of such conditions.

Keywords: Rheumatoid arthritis; Anti-TNF; Tumor necrosis factor inhibitor; Sarcoidosis; Drug-induced sarcoidosis

\section{Key Summary Points}

These cases of anti-TNF-induced sarcoidosis highlight this rare paradoxical side effect and the variability of clinical presentation. 


\section{INTRODUCTION}

Biological disease-modifying antirheumatic drugs (bDMARDs) have considerably improved the prognosis of rheumatoid arthritis (RA). The first and major bDMARDs used in RA were the tumor necrosis factor inhibitors (anti-TNF agent). Five original molecules and more recently many biosimilars are actually available: three monoclonal anti-TNF-a full IgG1 antibodies infliximab, adalimumab, and golimumab, PEGylated Fab' fragment of anti-TNF-a antibody certolizumab pegol, extracellular domain of TNF receptor $2 /$ IgG1-Fc fusion protein etanercept [1].

The use of anti-TNF agents is considered safe but a higher risk of infections is reported [2]. Among infections, reactivation of latent tuberculosis is possible and requires a strict evaluation before initiation with prophylaxis in positive cases. Another granulomatosis disease, sarcoidosis, is a rare side effect of anti-TNF agents and has also been observed with other drugs such as immune checkpoint inhibitors, antiretroviral therapy, and interferons [3]. This condition is clinically and pathologically indistinguishable from a classical sarcoidosis.

The etiology of sarcoidosis remains unknown and related to multiple factors. It is thought that a combination of environmental context on predisposed genetic background lead to the creation of granuloma around poorly soluble antigens [4]. The disease more often affects the lungs, skin, and lymph nodes but can infiltrate any organ. The clinical presentation and prognosis depend on the severity of inflammation and the involved organ. The course of the disease may range from spontaneously resolutive mild symptoms to lifethreatening events [5].

Treatment of sarcoidosis mainly includes corticosteroids, combined eventually with immunosuppressive agents and more recently biological agents such as anti-TNF [6].

Drug-induced sarcoidosis is therefore a paradoxical side effect such as anti-TNF-induced psoriasis [7]. The discontinuation of the antiTNF is the first recommendation combined to a standard care of the sarcoidosis.
The aim of this report was to analyze the rate of anti-TNF induced sarcoidosis in our RA UCLouvain Brussels cohort and to report the clinical aspects, treatment, and follow-up.

\section{METHODS}

We performed a retrospective analysis of our RA UCLouvain Brussels cohort. Inclusion criteria were RA patients fulfilling the 1987 and/or 2010 RA classification criteria. A total of 2492 dossiers of RA patients treated from November 1999 to October 2021 were reviewed. Among them, all 697 RA patients treated at any time with an anti-TNF agent were included.

The patients with high clinical suspicion of sarcoidosis or pathological proof of the disease were compiled. RA patients with another inflammatory or infectious pulmonary condition were excluded.

Our RA UCLouvain Brussels cohort has been approved by our academic institution and our local ethic committee for different protocol but not needed for such retrospective analysis.

\section{RESULTS}

Four patients treated by anti-TNF agent developed an anti-TNF induced sarcoidosis. They are listed and described below.

\section{Patients Characteristics}

The data are summarized in Tables 1 and 2 .

Patient 1: A 38-year-old female patient with seronegative RA presented with a painful swelling of bilateral parotids and complained of dyspnea without coughing.

She had been treated by etanercept for a total of 77 months with two interruptions, the first after achieving remission, and the second for pregnancy. No additional cDMARD (classical disease-modifying antirheumatic drugs) at the time, no steroid treatment.

A parotid biopsy showed noncaseing granulomas. The chest CT revealed pulmonary reticulonodular infiltrates. Additional extrapulmonary involvement in the spleen, 
Table 1 RA patients' characteristics

\begin{tabular}{|c|c|c|c|c|}
\hline & Case 1 & Case 2 & Case 3 & Case 4 \\
\hline Gender & $\mathrm{F}$ & $\mathrm{F}$ & $\mathrm{M}$ & $\mathrm{F}$ \\
\hline Age (years) & 38 & 61 & 66 & 73 \\
\hline $\begin{array}{l}\text { Disease duration } \\
\text { (years) }\end{array}$ & 13 & 22 & 21 & 6 \\
\hline Smoker & - & - & + & - \\
\hline Rheumatoid factor & - & - & + & + \\
\hline ACPA & - & + & + & + \\
\hline Erosive disease & - & + & + & + \\
\hline $\begin{array}{l}\text { Steroid } \\
\text { combination }\end{array}$ & No & $\begin{array}{l}\text { Yes } \\
\text { Prednisolone } \\
7.5 \mathrm{mg} / \text { day }\end{array}$ & $\begin{array}{l}\text { Yes } \\
\text { Methylprednisolone } 4 \mathrm{mg} / \text { day }\end{array}$ & No \\
\hline $\begin{array}{l}\text { Anti-TNF-time } \\
\text { exposure } \\
\text { (months) }\end{array}$ & $\begin{array}{l}\text { Etanercept (50 mg sc } \\
\text { weekly) } \\
77 \mathrm{~m} \\
\text { Two temporary } \\
\text { discontinuation } \\
\text { (4 years for } \\
\text { remission and for } \\
\text { pregnancy) }\end{array}$ & $\begin{array}{l}\text { Etanercept } \\
\quad(50 \mathrm{mg} \mathrm{sc} \\
\text { weekly) } \\
123 \mathrm{~m}\end{array}$ & $\begin{array}{l}\text { Etanercept (50 mg sc weekly) } \\
29 \mathrm{~m}\end{array}$ & $\begin{array}{l}\text { Infliximab }(3 \mathrm{mg} / \mathrm{kg} \text { every } \\
8 \text { weeks }) \\
9 \mathrm{~m}\end{array}$ \\
\hline $\begin{array}{l}\text { RA disease activity } \\
\text { at the time of } \\
\text { sarcoidosis onset } \\
\text { (DAS28-CRP) }\end{array}$ & 2.03 (remission) & $\begin{array}{l}2.76 \text { (low } \\
\text { disease } \\
\text { activity) }\end{array}$ & 2.42 (remission) & 2.6 (low disease activity) \\
\hline $\begin{array}{l}\text { Methotrexate } \\
\text { combination- } \\
\text { time exposure }\end{array}$ & No & $\begin{array}{l}\text { Yes } \\
20 \mathrm{mg} \text { weekly } \\
12 \text { years }\end{array}$ & $\begin{array}{l}\text { Yes } \\
15 \mathrm{mg} \text { weekly } \\
9 \text { years }\end{array}$ & $\begin{array}{l}\text { Yes } \\
15 \mathrm{mg} \text { weekly } \\
6 \text { years }\end{array}$ \\
\hline RA evolution & $\begin{array}{l}\text { Remission on } \\
\text { methotrexate }\end{array}$ & $\begin{array}{l}\text { Stable without } \\
\text { any } \\
\text { bDMARD }\end{array}$ & $\begin{array}{l}\text { Initiation of abatacept for RA } \\
\text { flare-up } 2 \text { years after } \\
\text { etanercept discontinuation. } \\
\text { Low disease activity } \\
\text { afterwards }\end{array}$ & $\begin{array}{l}\text { RA flare after Infliximab } \\
\text { discontinuation, } \\
\text { abatacept not effective, } \\
\text { improved on rituximab }\end{array}$ \\
\hline
\end{tabular}

sc sub cutaneous 
Table 2 Sarcoidosis clinical features

\begin{tabular}{|c|c|c|c|c|}
\hline & Case 1 & Case 2 & Case 3 & Case 4 \\
\hline $\begin{array}{l}\text { Clinical } \\
\text { presentation }\end{array}$ & $\begin{array}{l}\text { Bilateral parotid } \\
\text { swelling } \\
\text { Dyspnea }\end{array}$ & $\begin{array}{l}\text { Asthenia } \\
\text { Dyspnea } \\
\text { B symptoms }\end{array}$ & $\begin{array}{l}\text { Asthenia } \\
\text { Fatigue } \\
\text { Dyspnea }\end{array}$ & Chronic cough \\
\hline $\begin{array}{l}\text { Pulmonary } \\
\text { involvement }\end{array}$ & $\begin{array}{l}\text { Reticulonodular } \\
\text { infiltrates }\end{array}$ & $\begin{array}{l}\text { Interstitial lung disease } \\
\text { “Crazy-paving pattern” on } \\
\text { CT }\end{array}$ & Interstitial lung disease & $\begin{array}{l}\text { Interstitial lung disease } \\
\text { and pulmonary } \\
\text { fibrosis with "sarcoid- } \\
\text { like pattern" }\end{array}$ \\
\hline $\begin{array}{l}\text { Extra- } \\
\text { pulmonary } \\
\text { involvement }\end{array}$ & $\begin{array}{l}\text { Bilateral parotitis } \\
\text { Spleen } \\
\text { Muscle } \\
\text { Multiple adenopathy }\end{array}$ & No & No & No \\
\hline $\begin{array}{l}\text { Positive } \\
\text { laboratory } \\
\text { results }\end{array}$ & $\begin{array}{l}\text { High ACE }(216 \\
\text { UECA) } \\
\text { High CRP } \\
(51.2 \mathrm{mg} / \mathrm{l})\end{array}$ & $\begin{array}{l}\text { Severe hypercalcemia } \\
(13.37 \mathrm{mmol} / \mathrm{l}) \\
\text { Acute kidney injury (max } \\
\text { creatinine } 3.54 \mathrm{mg} / \mathrm{dl}) \\
\text { Bicytopenia } \\
\text { Normal values of } \\
\text { lysozyme and ACE }\end{array}$ & High CRP $(134 \mathrm{mg} / \mathrm{l})$ & $\begin{array}{l}\text { Slightly high CRP } \\
\quad(31 \mathrm{mg} / \mathrm{l})\end{array}$ \\
\hline Biopsy & $\begin{array}{l}\text { Noncaseating } \\
\text { granulomas in } \\
\text { parotid biopsy }\end{array}$ & $\begin{array}{l}\text { No granuloma were } \\
\text { found on the renal } \\
\text { biopsy }\end{array}$ & $\begin{array}{l}\text { Noncaseating granulomas } \\
\text { in hilar adenopathy }\end{array}$ & No \\
\hline Treatment & $\begin{array}{l}\text { Methylprednisolone } \\
\text { pulses }(3 \times 1 \mathrm{gr}) \\
\text { Methotrexate } \\
\text { initiation } \\
\text { Oral prednisolone } \\
15 \mathrm{mg} / \text { day and } \\
\text { tapering over } \\
4 \text { months } \\
\text { Discontinuation of } \\
\text { etanercept }\end{array}$ & $\begin{array}{l}\text { Discontinuation of } \\
\text { etanercept and } \\
\text { methotrexate } \\
\text { Prednisolone } 7.5 \mathrm{mg} \\
\text { continued (chronical } \\
\text { dose for RA) }\end{array}$ & $\begin{array}{l}\text { Discontinuation of } \\
\text { etanercept and } \\
\text { methotrexate, } \\
\text { Oral methylprednisolone } \\
32 \mathrm{mg} / \text { day and tapering to } \\
4 \mathrm{mg} \text { (chronical dose for } \\
\mathrm{RA} \text { ) }\end{array}$ & $\begin{array}{l}\text { Discontinuation of } \\
\text { infliximab }\end{array}$ \\
\hline $\begin{array}{l}\text { Clinical } \\
\text { Follow-up }\end{array}$ & $\begin{array}{l}\text { Complete clinical } \\
\text { recovery after } \\
3 \text { months } \\
\text { Regression of } \\
\text { pulmonary } \\
\text { infiltrates } \\
\text { No relapse }\end{array}$ & $\begin{array}{l}\text { Complete renal recovery } \\
\text { after } 1 \text { month. Light } \\
\text { sequelae of pulmonary } \\
\text { fibrosis } \\
\text { No relapse }\end{array}$ & $\begin{array}{l}\text { Complete clinical recovery } \\
\text { after } 3 \text { months } \\
\text { No relapse }\end{array}$ & $\begin{array}{l}\text { Cessation of the cough } \\
\text { Persistence of the } \\
\text { pulmonary infiltrates } \\
\text { No clinical relapse }\end{array}$ \\
\hline $\begin{array}{l}\text { Follow-up } \\
\text { duration }\end{array}$ & 8 months & 40 months & 130 months & 44 months \\
\hline
\end{tabular}

$A C E$ angiotensin-converting enzyme, $C T$ computed tomography, $C R P$ C-reactive protein 
muscle, and multiples adenopathies were found by FDG-Pet CT.

High angiotensin-converting enzyme (ACE) and elevated C-reactive protein (CRP) were shown in the laboratory test.

Etanercept was withdrawn and a treatment with three IV-pulses and oral glucosteroids was started and tapered over 4 months. Despite the patient's reluctance, we added methotrexate to the treatment with favorable evolution and absence of either relapse of the sarcoidosis or RA flare after 8 months of follow-up.

Patient 2: A 61-year-old female patient presented with acute confusion, flu-like symptoms, and global weakness. She complained of dysphagia leading to a weight loss of $3 \mathrm{~kg}$ after 1 week, fever, and dyspnea without coughing. Her past medical history consisted of 22 years RA that was treated with steroids, methotrexate for 12 years, and for about 10 years with etanercept.

On clinical examination, the patient was bradypsychic and under oxygenotherapy. Pulmonary auscultation revealed basal crepitants were heard. Laboratory test showed a raised CRP, non-regenerative anemia, thrombocytopenia, and severe hypercalcemia with acute kidney injury. ACE was normal. Immunological and infectious serologies were negative.

CT scan of the thorax showed interstitial lung disease with a "crazy paving pattern", the bronchial lavage remained aseptic and did not contribute for the diagnosis. A renal biopsy did not reveal any granulomas; a lower lip salivary gland biopsy was not performed. Without pathological evidence, we nevertheless conclude it to be a drug-induced sarcoidosis-like disease.

Cessation of the anti-TNF treatment and methotrexate with continuation of the same dose of prednisolone on top of quick care of the hypercalcemia led to complete clinical and biological recovery. A control thorax CT scan later revealed light pulmonary fibrosis with no sign of active sarcoidosis.

Methotrexate was reinitiated at a lower dose 6 months later. During 4 years of follow-up, the patient remained with a low disease activity score and no relapse of sarcoidosis was reported. Steroids were not withdrawn but tapered.
Patient 3: A 66-year-old male with RA treated by steroids, etanercept for over 2 years and methotrexate for 9 years presented with fatigue and dyspnea. He underwent chest X-ray, where an interstitial infiltrate and hilar adenopathies were found. In addition, blood testing revealed high CRP without any other abnormality. Lymph node biopsy during mediastinoscopy showed typical noncaseing granulomas. The patient recovered progressively after anti-TNF therapy, methotrexate discontinuation, and oral steroid treatment.

A flare of RA was observed 2 years after the withdrawal of the anti-TNF agent and abatacept combined with methotrexate were initiated. The patient is still in remission after 9 years of follow-up.

Patient 4: A 73-year-old female RA patient treated and well controlled by infliximab and methotrexate presented with long-lasting couch. No fever or other complaints were observed. Laboratory findings showed only a slightly elevated CRP.

Chest CT scan revealed a sarcoid-like pattern with hilar adenopathies. Withdrawal of the infliximab therapy with moderate dose of oral steroids was sufficient to improve the patient's condition. Infliximab was first switched to abatacept with no efficacy, then to rituximab with a progressive response. No clinical relapse of sarcoidosis was observed but persistence of pulmonary signs was described on CT.

\section{DISCUSSION}

In our large cohort, only four cases of sarcoidosis induced by an anti-TNF agent were observed during a 20-year period. The incidence of this side effect is unknown. We have analyzed all published manuscripts on this topic. Thirty-nine cases of RA patients who developed anti-TNF induced granulomatosis were found, mainly female patients treated with etanercept [8-32]. The etiology of sarcoidosis is still unknown and has been linked to infectious agents like Mycobacterium, Cutibacterium, Propionibacterium species, organic agents, and specific HLA predisposition [4, 33]. Sarcoidosis patients may present similar patterns of cellular 
immune dysregulation observed in auto-immune disease like RA. It could be present with other autoimmune diseases such as Sjögren's syndrome [34] but the association with RA is very rare. Our report confirms the facilitating role of TNF inhibition to develop sarcoidosis. This is a paradox since TNF blood level is correlated to disease severity [35]. TNF- $\alpha$ is also involved in the granuloma's formation and maintenance, and produced, among others, by pulmonary monocytes and macrophages. Blocking TNF is therefore a new and potent treatment of severe and refractory sarcoidosis [6]. However, we know that TNF inhibitors are also associated with the reactivation of latent tuberculosis, another granulomatosis disease. TNF-induced psoriasis, another paradoxical phenomenon, has also been described in RA patients [7]. The first observation of TNF agentinduced sarcoidosis was reported in 2002 [14]. In France, ten cases including four RA patients were reported by the Club Rhumatismes et Inflammation (CRI), with a calculated incidence of $1 / 2800$. The incidence in our cohort is $4 / 700$, which demonstrates that a systematic review of RA cohort or registries would reveal a larger number of cases. The mean time of anti-TNF agent exposure is highly variable in the literature and vary in our cases between 7 and 123 months. This suggests that other triggers like an infectious agent may be associated with this paradoxical disease. The clinical presentation in terms of organ involvement and severity is very heterogeneous. One of our four cases was critically ill with severe hypercalcemia, bicytopenia, and kidney failure. This case was admitted to the intensive care unit. The main treatment consideration is the discontinuation of the anti-TNF agent. Methotrexate, an active treatment for sarcoidosis, has not been evaluated in such conditions and we consider that methotrexate should be maintained or considered in these patients [6]. Some reports have indicated that a restart of an anti-TNF is possible but some relapses have been reported [28]. We decided not to re-challenge any of our four patients with an anti-TNF agent as there are other biotherapy available for RA.

The strength of our review is the strict analysis of a large prospective RA cohort treated with a TNF inhibitor. The limitation is the absence of blood and tissue analysis to better understand such rare associations.

In conclusion, sarcoidosis during anti-TNF therapy in RA patients is not uncommon. The etiology is multifactorial, but the role of the therapy is to accelerate such a paradoxical reaction. Clinicians should be vigilant when patients present fever, asthenia, dyspnea, or granulomatosis lesions. The differential diagnosis remains tuberculosis. Future research is needed to better define the incidence and to analyze the associative role of infectious agents.

\section{ACKNOWLEDGEMENTS}

We thank the patients for their contribution for this study.

Funding. The study and the journal's Rapid Service Fee were funded by the authors.

Authorship. All named authors meet the International Committee of Medical Journal Editors (ICMJE) criteria for authorship for this article, take responsibility for the integrity of the work as a whole, and have given their approval for this version to be published.

Authors Contributions. All authors X T, L B, S D, E S, T S, A A and P D analyzed and interpreted the patients data; $\mathrm{X} \mathrm{T}$ and $\mathrm{P} \mathrm{D}$ in addition were major contributors in writing the manuscript. All authors X T, L B, S D, E S, T S, A $\mathrm{A}$ and $\mathrm{P}$ D read and approved the final manuscript.

Disclosures. Xavier Theunssens, Laura Bricman, Stéphanie Dierckx, Emilie Sapart, Tatiana Sokolova, Aleksandra Avramovska and Patrick Durez have nothing to disclose.

Compliance with Ethics Guidelines. This retrospective non-interventional study was retrospectively registered with local ethics approval. No additional consent form needs for this retrospective non-interventional SOC study. Institutional consent form was used for publication. 
Data Availability. All data were collected in medical record files of Cliniques universitaires Saint-Luc, UCLouvain, Brussels, Belgium. The datasets generated during and/or analyzed during the current study are available from the corresponding author on reasonable request.

Open Access. This article is licensed under a Creative Commons Attribution-NonCommercial 4.0 International License, which permits any non-commercial use, sharing, adaptation, distribution and reproduction in any medium or format, as long as you give appropriate credit to the original author(s) and the source, provide a link to the Creative Commons licence, and indicate if changes were made. The images or other third party material in this article are included in the article's Creative Commons licence, unless indicated otherwise in a credit line to the material. If material is not included in the article's Creative Commons licence and your intended use is not permitted by statutory regulation or exceeds the permitted use, you will need to obtain permission directly from the copyright holder. To view a copy of this licence, visit http:// creativecommons.org/licenses/by-nc/4.0/.

\section{REFERENCES}

1. Mitoma $\mathrm{H}$, Horiuchi $\mathrm{T}$, et al. Molecular mechanisms of action of anti-TNF- $\alpha$ agents - comparison. Cytokine. 2018;101:56-63.

2. Goh L, Jewell T, et al. A systematic review of the influence of anti-TNF on infection rates in patients with rheumatoid arthritis. Rev Bras Reumatol. 2013;53(6):501-15.

3. Cohen Aubart F, Lhote R, et al. Drug-induced sarcoidosis: an overview of the WHO pharmacovigilance database. J Intern Med. 2020;288:356-62.

4. Yamaguchi $\mathrm{T}$, Costabel $\mathrm{U}$, et al. Immunohistochemical detection of potential microbial antigens in granulomas in the diagnosis of sarcoidosis. J Clin Med. 2021;10:983.

5. Drent $\mathrm{M}$, Crouser ED, et al. Challenges of sarcoidosis and its management. $\mathrm{N}$ Engl J Med. 2021;385:11.
6. Baughman RP, Valeyre D, et al. ERS clinical practice guidelines on treatment of sarcoidosis. Eur Respir J. 2021;58(6):2004079.

7. Collamer AN, Guerrero KT, Henning JS, Battafarano DF. Psoriatic skin lesions induced by tumor necrosis factor antagonist therapy: a literature review and potential mechanisms of action. Arthritis Rheum. 2008;59(7):996-1001.

8. Daïen CI, Monnier A, et al. Sarcoid-like granulomatosis in patients treated with tumor necrosis factor blockers: 10 cases. Rheumatology. 2009;48(8):883-6.

9. Durel CA, Feurer E, et al. Etanercept may induce neurosarcoidosis in a patient treated for rheumatoid arthritis. BMC Neurol. 2013;28(13):212.

10. Hübscher $\mathrm{O}$, Re $\mathrm{R}$, et al. Pulmonary rheumatoid nodules in an etanercept-treated patient. Arthritis Rheum. 2003;48(7):2077-8.

11. Ishiguro $\mathrm{T}$, Takayanagi $\mathrm{N}$, et al. Development of sarcoidosis during etanercept therapy. Intern Med. 2008;47(11):1021-5.

12. Kanellopoulou T, et al. Sarcoid-like granulomatosis in patients treated with anti-TNF $\alpha$ factors. A case report and review of the literature. Clin Rheumatol. 2011;30:581-3.

13. Isshiki $\mathrm{T}$, Matsuyama $\mathrm{H}$, et al. Development of propionibacterium acnes-associated sarcoidosis during etanercept therapy. Intern Med. 2019;58(10):1473-7.

14. Peno-Green L, Lluberas $G$, et al. Lung injury linked to etanercept therapy. Chest. 2002;122(5):1858-60.

15. Kudrin A, Chilvers ER, et al. Sarcoid-like granulomatous disease following etanercept treatment for RA. J Rheumatol. 2007;34(3):648-9.

16. Scailteux LM, Guedes C, et al. Sarcoïdose survenant chez des patients traités par adalimumab pour un rhumatisme inflammatoire : à propos de deux cas et revue de la littérature. Press Med. 2015;44(1):4-10.

17. Massara A, Cavazzini L, et al. Sarcoidosis appearing during anti-tumor necrosis factor alpha therapy: a new "class effect" paradoxical phenomenon. Two case reports and literature review. Semin Arthritis Rheum. 2010;39(4):313-9.

18. Miyagi R, Ideguchi $\mathrm{H}$, et al. Development of pulmonary and cardiac sarcoidosis during etanercept therapy. Int J Rheum Dis. 2014;17(7):810-2.

19. Ngoufack C, Semerano L, et al. Mitral valve granulomatosis: a paradoxical reaction complicating 
etanercept treatment in rheumatoid arthritis. Jt Bone Spine. 2021;88(4):105183.

20. Rodrigues-Fernandes CI, Migliorati CA, et al. Adalimumab-induced sarcoidosis-like reaction involving oral cavity in rheumatoid arthritis: a case-based review. Clin Rheumatol. 2021;40(9):3833-9.

21. Salvatierra J, Magro-Checa C, et al. Acute sarcoidosis as parotid fever in rheumatoid arthritis under anti-tumor necrosis factor-alpha therapy. Rheumatology. 2011;50(7):1346-8.

22. Sawahata M, Sugiyama Y, et al. Sarcoidosis during etanercept treatment for rheumatoid arthritis in women with a history of bilateral oophorectomy. Sarcoidosis Vasc Diffuse Lung Dis. 2016;33(2): 178-81.

23. Seve P, Varron L, et al. Sarcoid-related uveitis occurring during adalimumab therapy. Ocul Immunol Inflamm. 2012;20(1):59-60.

24. Skoie IM, Wildhagen K, et al. Development of sarcoidosis following etanercept treatment: a report of three cases. Rheumatol Int. 2012;32(4):1049-53.

25. Sturfelt G, Christensson B, et al. Neurosarcoidosis in a patient with rheumatoid arthritis during treatment with infliximab. J Rheumatol. 2007;34(11): 2313-4.

26. Tong D, Manolios N, et al. New onset sarcoid-like granulomatosis developing during anti-TNF therapy: an under-recognised complication. Intern Med J. 2012;42(1):89-94.

27. Unterstell N, Bressan AL, et al. Systemic sarcoidosis induced by etanercept: first Brazilian case report. An Bras Dermatol. 2013;88(6 Suppl 1):197-9.
28. van der Stoep D, Braunstahl GJ, et al. Sarcoidosis during anti-tumor necrosis factor-alpha therapy: no relapse after rechallenge. J Rheumatol. 2009;36(12): 2847-8.

29. Vavricka SR, Wettstein T, et al. Pulmonary granulomas after tumour necrosis factor alpha antagonist therapy. Thorax. 2003;58(3):278-9.

30. Verschueren K, et al. Development of sarcoidosis in etanercept-treated rheumatoid arthritis patients. Clin Rheumatol. 2007;26:1969-71.

31. Ognenovski VM, Ojo TC, et al. Etanercept-associated pulmonary granulomatous inflammation in patients with rheumatoid arthritis. J Rheumatol. 2008;35:2279-82.

32. Watrin A, Royer M, et al. Hypercalcémie majeure révélatrice d'une sarcoïdose induite par étanercept [Severe hypercalcemia revealing sarcoidosis precipitated by etanercept]. Rev Mal Respir. 2014;31(3): 255-8.

33. Barna B, Malur A, Thomassen M. Studies in a murine granuloma model of instilled carbon nanotubes: relevance to sarcoidosis. Int $\mathrm{J}$ Mol Sci. 2021;22:3705.

34. Terwiel M, Grutters JC, et al. Clustering of immunemediated diseases in sarcoidosis. Curr Opin Pulm Med. 2019;25(5):539-53.

35. Lepzien R, Liu S, et al. Monocytes in sarcoidosis are potent TNF producers and predict disease outcome. Eur Respir J. 2021;58(1):2003468. 